Nedeljko Prdić ${ }^{1}$

JKP Tržnica, Novi Sad

Boris Kuzman ${ }^{2}$

Institute of Agricultural Economics, Belgrade
SCIENTIFIC REVIEW ARTICLE doi:10.5937/ekonomika1901107P

Received December, 11, 2018

Accepted: February, 26, 2019

\title{
THE IMPORTANCE OF AUCTIONS FOR AGROINDUSTRIAL PRODUCTS TRADE
}

\begin{abstract}
The aim of this paper is research of the importance of auctions for wholesale of agro-industry products. Based on theoretical and scientific knowledge, the result that would encourage auction trade is demanded. The basic goal is, through the analysis of auction importance for trade, to affirm information and conclusions that may show that wholesale markets are appropriate place for auction trade in agro-industry. Therefore, the aim is to achieve expected result on the market, by auction trade, etc. by bid based on and equivalent to expected incomes. However, auctions are classical example of trade with mutual depended valuations, so theoretical and empirical researches tend to achieve the effect of efficiency and maximum revenue.
\end{abstract}

Key words: auctions, trade, market, wholesale market, agro-industry products

JEL Classification: Q1, 012

\section{ЗНАЧАЈ АУКЦИЈА ЗА ТРГОВИНУ АГРОИНДУСТРИЈСКИМ ПРОИЗВОДИМА}

Апстракт

Циљ рада је истраживање значаја аукиија за трговину агроиндустријским производима на велико. На основу теоријских и научних сазнања жели се постићи такав резултат који ће подстаћи трговину путем аукиија. Основни ичиљ је да се кроз анализу значаја аукција за трговину, афирмишу информације и закључции који могу показати да су велетржниче повољно место за аукиијску продају у агроиндустрији. Дакле, ииљ је постићи очекивани резултат на тржишту, трговином путем аукција, методом лицитације који ће бити заснован и еквивалентан очекиваним приходима. Међутим, аукције представљају класичан пример трговине са међузависним вредновањима па се теоријским и емпиријским истраживањима жели постићи ефекат ефикасности и максималног прихода.

Кључне речи: аукиије, трговина, тржиште, велетржница, агроиндустријски производи

\footnotetext{
${ }^{1}$ ekonomistdoo@sbb.rs

22kuzmanboris@yahoo.com
} 


\section{Introduction}

Auctions are kind of specialised market institutions that originate from ancient times. As market and trade forms, auctions have been present from $500 \mathrm{BC}$. When we speak of the importance of modern auction for trade, it is necessary to mention interest of governments, states and economists for their importance on oil market. It is not necessary to stress how important oil is for world trade, but for the purposes of this paper it could be necessary, in the sense of presentation the importance of auctions for global trade. In the middle of the 1970 s, economists from all over the world shown greater interest for practical implementation of auctions in trade. Namely, the aim of research of importance and role of auctions in trade, was finding the most efficient strategies and plan for their realisation in the market. Modern business conditions and usage of the Internet contributed to development of auction trade and sales of different goods and services orientated to consumers. Also, it is necessary to stress the importance of so-called occasional auctions for goods that are rarely on market but may have great economic value and price, such as antiquities and artefacts with great artistic value. In the focus of analysis in this paper is the agro-industry products market and importance of auctions for the trade. When speaking about agro-industry products trade, it is important to point out the importance of bazaars and fairs as the oldest market institutions but also modern trade places as wholesale markets. For domestic and international trade, of great importance are regular auctions organised in regular time intervals with recognisable and well known goods. Fairs may be very efficient places for auction trade,f they are significant and recognisable in agro-industry. For these trading places time intervals are very significant and it is recognised in agriculture and agro-industry. The special aim of this work is to stress the relevance of wholesale markets as places for auction whole sales of agro-industry products. The main role of private, public or state wholesale markets is organisation of auction trade, providing place and monitoring the course of auctions. This is all necessary in such markets.

\section{Definition - forms and place of auctions in trade}

Auctions are among the oldest market institutions. They were held in places where many people have gathered, such as squares and during church ceremonies. Like bazaars, fairs also originate from ancient times. With certainty it is possible to say that they are the oldest forms of trade. If we say that some forms of trades are important for the development of trade for centuries, being improved by development of production forces and transport, it is however not necessary to stress it in the this case.

The word "auction" originates from Latin word „Auctio“ that means lifting. First auctions were organised in Ancient Rome. It is interesting to mention they were held on squares. The aim of auctions was the protection of interests of the absent and incapable, whose property was being sold. Later, this selling manner was used for sale of debtor's property, by court decision, to pay debtor's obligations. (Acin-Sigulinski, 2008).

Auction is a specialised market institution where the goods are sold by public sale - the bidding. The first price is determined by salesman, and the buyer who offers the highest price becomes the owner. The price is formed by bidding of potential buyers. The 
owner of goods is the buyer who offers the most, so they have the right to buy wanted quantity at the offered price.

Auction in modern market economy is international market institution where the sale of goods is made by bidding and bidding is the method for achieving the maximum price. By opinion of the author of this paper - auctions are organised markets in which irreplaceable goods in strictly determined places and at the specified time, that fulfill all legal and security conditions for objective trade. There are different types of auctions, depending on aims they tend to achieve. According to the criterion of permanence, there are:

1. Occasional auctions - for goods that are rarely sold

2. Regular auctions - organised in public places with known methods of bidding.

When we speak about he significance of auctions for agricultural products trade, it is important to stress the relevance of regular auctions, because of the trade of familiar goods and because of the permanent place for auctions. Auctions may be:

1. Retail auctions and

2. Wholesale auctions.

When it comes to wholesale auctions, there are private companies, public or other economic entities engaged in organizing auctions, providing space and supervision services to traders operating in such markets. Auction companies provide auction organising services but do not participate in the trade themselves. The most important services of the auction companies are

- Providing the premises suitable for trade

- Organizing an auction store in terms of traders' records and trading standards

- Conducting a bid flow

- They inform interested companies and the rest of the public about the prices achieved at the auctions.

In order to clarify the concept of trading, it should be noted that auctions are traded by auction brokers that are registered with an auction company (house) for trade in auctions. These companies represent buyers at the auction (brokers) because it is in the interest of buyers to use the brokers' expertise, knowledge and confidence in achieving the appropriate price. There are also appropriate mechanisms for protecting the interests of buyers in the trade (bills) in the name of the company, bank guarantees and other types.

Auction types:

\section{$\square$ English type}

The type of auction in which auctioneer begins to trade with the lowest acceptable price. The essence of this trading form is that buyers bid offers up to maximum acceptable for certain buyer.

\section{Dutch type of auctions}

The type of auction that begins with the highest price which gets lower until some buyers agree to buy. 
Auctions of sealed offers. (Đorđević et al. 2008).

This is the type of auctions in which participants give their offers in sealed form, so other participants do not know what the offer is. This type of auction consists of two parts, the first is the delivery of offers, and the second is opening of offers and announcement of winner and the highest price.

In 1797 Johann Wolfgang von Goethe sold his handwriting using auction of sealed offers. (Benni et al. 1998).

Steps for auction preparation:

- Preparation of auction plan

- Choice of auction form

- Development of auction rules

- Announcing in media

- Registration of participants and distribution of auction documentation

- Maintenance of auction

- Sale contract finalisation

- Conclusion of auction. (Đorđević et al. 2008).

Auction process:

1. Auction preparation:

- Delivering goods on the address

- Classification and separation in lots

- Putting goods in an auction store for inspection

- Promotion of auctions - sending of auction lists (place and date of auction, name of auctionrer, description of goods, description of each particular lot)

2. Auction bidding:

- Announcement of opening

- $\quad$ Bidding

- Making contracts, taking goods for another auction sale, or withdrawal of goods. (Acin-Sigulinski, 2008).

Trade of agricultural products on fairs, wholesale markets and other trading places is specific due to:

1. Manner of organising

2. Price determination

3. Standardisation of goods and services that are exhibited or sold.

The specificity of trade in the agro-industry stems from the importance of these products for the health and life of the population. On the auction itself, there are experts who know the rules and standards in the agro-industry. The sale is performed by agents intermediaries, who accept goods which is considered to be interesting for potential buyers They are the ones who determine the starting price and sell it in their own name and for the account of the owner. These are salesmen brokers. Depending on the type of auction and the reasons for the organisation of the trade, there are brokers who perform the buying on their behalf and for the account of the clients. It should be noted that both types of brokers charge a commission from sellers or customers. When it comes to agrofood or agro-industrial products sold at the auction, it should be noted that this is a sale of 
non-standardised goods, which means that their quality cannot be accurately determined, so there is a need, before and sometimes during auctions, to be present in the premises. Based on the above, we can conclude that in terms of the quality of purchased and sold goods, wholesale markets represent the most efficient and important place for auction trade in agro-industrial products.

\section{Research results}

\section{The importance of auctions from the aspect of trade}

Modern approach to auction theory is seen in theorem of equivalency of expected incomes. This theorem is assuming that bidding participants have private values and they are neutral to the risk and also symetrical (functions of probability allocation are identical), English, Dutch, auction on first-price and second-price bring the the same expected income to seller. If some of assumptions is not fulfilled, different kinds of auctions would generate different level of expected income to seller. It is necessary to mention that there are licitation participants that are reluctant to risk, and on second-price auction they would make an offer equal to the value. However, on the first-price auction, a bidding participant has a dilemma. If he lowers the offer in relation to its value, he would pay less if he wins, but probability for winning is lower. If bidding participant is reluctant to risk, it is more important for him to win but to pay less, so he will slightly lessen his offer on the value, and first price auction brings greater expected income to seller then second-price auction. Course of auction and expected income depends on the number and power of bidding participants. The important market moment during auctions may create an opportunity for bidding participants to operate cooperatively and form a cartel in order to generate greater profit on account of the seller who generates lower expected income. We may say that each kind of auction has its advantages and disadvantages, therefore combination of auctions are common in the practice. For example, in an English-Dutch auction, the first phase is an English auction until two participants remain. Afterwords, they participate in first-price auction. Dutch-English auctions have opposite order. Combining them encourages greater number of participants on bidding, who may also get a certain premium. On the bases of performed researches, we may conclude that auctions with great number of participants are very significant instrument for wholesale trade of agro-industrial products.

Auctions studied by Vickrey are known as sealed auctions, since proposals are given in sealed envelopes. On the sealed first price auctions, participant who offers the highest price gets the goods and pays the amount he had offered. On sealed bid secondprice auctions, buyer who had offered the highest price gets goods, and pays the price equal to second highest amount.

Vickrey's auctions are greatly studied in economic literature, but they are unusual in practice. There are generalized variations of Vickrey's auction for multiplies auctions, such as generalized second-price auction. (Benjamin i dr, 2007).

Analysing modern type of agro-industrial products trade, the conclusion is that wholesale markets are the most organised and most efficient form of wholesale trade. From the aspect of efficient management aiming to achieve efficiency effect and 
maximum revenue through auction sales, wholesale markets represent a well organised, permanent place of trade. Having in mind experiences and practical usage of wholesale markets in wholesale trade in developed economies, mainly for fruit and vegetables, we may conclude that they enable a trade increase and efficient distribution of agro-industrial products. An efficient management of the company or part of an auction company is also an effective tool for achieving the efficiency and effectiveness of increasing auctioning through auctions.

\section{The importance of wholesale markets as a place for trade}

Wholesale market, as a company or a part of an auction company, offers organising services but does not participate in the trade itself. Modern world agricultural production attaches enormous importance to healthy nutrition and food safety within the overall agro-industrial complex. The agrarian world economy is engaged in research on the importance of sustainable development of agriculture and especially areas that are, by their nature, suitable for the development of this type of industry. These places of trade create the necessary preconditions for the sale of large quantities of goods, controlled quality, domestic and foreign customers of controlled health safety. The importance of auctions for trade in agro-industrial products can be seen by comparing domestic trade as well as the share of domestic enterprises in regional, European and world trade.

The policy of reliance on the agrarian and rural economy as a whole would have to be, not only in the function of survival in the present times, but also a lasting determination of our country and economic development policy based on decentralisation and harmonious economic development. (Jovanović, 2013)

Wholesale markets are specialised market institutions aimed at supplying a larger volume of agricultural products market, primarily fruits and vegetables. At these market institutions, wholesale trade is made available to the agro-industrial products and therefore their impact is very important for concentration of total supply and demand in the agroindustry. Due to their specificity in trade, they may be trade institutions with a non-standardized or standardised trading process. The market form of the organisation of wholesale markets depends on its legal form, its role and importance on the market. Therefore, it is necessary to emphasise that wholesale markets can also organise the sale of goods through auctions.

The wholesale market is a special market institution that deals with the organisation of wholesale trade, by regulating, maintaining and issuing specialised space for exhibiting and selling fruits, vegetables and other agricultural and food products, other consumer goods, as well as the provision of accompanying services, and in particular the storage of goods, its processing, processing, packaging and other services related to handling and transportation. The Wholesale Market is a legal entity registered for carrying out activities of wholesale organisation in accordance with regulations on the registration of economic entities. Sales at wholesale markets are traded by traders. Wholesaling is done wholesale and exceptional retail trade under the conditions prescribed for the market. (Zakon o trgovini, 2013).

Modern approach involves the use of wholesale markets as a special form of trade in order to achieve the goals of the company in the market, the greater the volume of trade, the quality of the service provided as a competitive advantage, in order to satisfy the interests of customers and end-users. (Kuzman et al. 2017). 
In developed countries, wholesale markets are one of the most important market institutions in agricultural products trade. (Kuzman et al. 2018).

The significance of wholesale markets from the aspect of total trade in agroindustrial products is great, but they can have a special role as places for trade through auctions. As a place of auction sale, they can have an informative role at the regional and national market level, especially for buyers and sellers of goods in the seat area. Their informative role is important from the aspect of reporting through electronic and printed media as well as media from the field of agro-industrial complex. Their role in the global auctioning site is reflected in ensuring the maximum supply of fruits and vegetables, cereals, increasing domestic supply and production, low prices and continuity of trading that enable adaptability to seasonal fluctuations in prices.

\section{Recommendations for the future of the market by the development of auction sales}

The concept of the development of wholesale markets as market institutions needs to be adapted to the already established standards in world trade in agro-industrial products. With a strategic approach to the development of these institutions in wholesale, it is necessary to develop a system of trade based on samples, by reference to certain standards, description and quality of products and in an auction manner. In particular, we can emphasise that the sale through auctions in the world trade is increasingly taking place in the direct presence of goods at the wholesale market, with the aim of ensuring the quality of goods, food safety and human health, as well as the price for purchased goods. Therefore, it is necessary to emphasise the role and significance of wholesale markets for the auction trade in terms of ensuring all modern standards of storage and warehousing of goods already applied in market-developed economies.

The research showed that irrigation increases the efficiency of agricultural production, influences the change of the seed structure, and market surpluses can be placed on the international market by using the existing international agreements signed by the Republic of Serbia. (Mihailović et al. 2014).

The results of the research show that the improvement of the competitiveness of the agricultural sector in the Municipality of Stara Pazova requires the implementation of adequate strategic measures and projects in the field of improvement of human potential, higher level of processing of agricultural products, as well as better agrotechnical equipment of agricultural producers. (Mihailović et al. 2017).

Competitiveness is a combination of the best methods and business models in a market in which a consumer, buyer or other interested entity in the market finds common goals with an enterprise in the form of purchasing an acceptable product or service for satisfaction and usefulness in a commercially acceptable manner. (Prdić, 2017)

In order to meet the demands of more and more exciting customers, both in the domestic and foreign markets, strengthening the competitiveness of the domestic economy imposes, inter alia, the need for programmes that will improve agricultural and rural development. (Subić, 2017)

Advantages of auction trade on wholesale markets of agro-industry products are:

- The development strategy of trade and agro-industry complex of the Republic of Serbia 
- Huge interest of buyers for auction trade and trade on wholesale markets

- Improvement of trade conditions by building and revitalisation of modern wholesale markets

- Aggregate sales in trade of agricultural goods (fruits and vegetables, grains)

- Implementation of European and world experiences in wholesale trade of agricultural goods

- Opportunity for organised and planned export of products on other markets

- Trade of organic and healthy food with controlled origin and safety

- Wholesale buyers' preference for auctions and wholesale markets as specialised market institutions but also attitudes and perception of consumers, for quality, price and freshness of products.

Disadvantages of auction trade on wholesale markets of agro-industry products are the following:

- Uncontrolled influence of wholesale network, especially in import of fruit and vegetables

- Inadequate development strategy and market rules

- Absence of export strategy for wholesale market that is enabled by auctions

- Strengthening of regional competition

- Traffic, infrastructural and information disbalance

- The lack of organised export on free markets (Russia) etc.

Based on the views of well-known experts on the importance of agriculture and the development of the market for agricultural products, the conclusion is simple and unique - the auctions are an effective type of wholesale trade.

\section{Conclusion}

Based on the conducted research, it can be concluded that auctions are a very important segment of the trade in the market, depending on whether it is a trade in products of special value or goods. The task of this paper was to examine the importance of auctions in trade in agro-industrial products as well as what effects they can achieve on business efficiency. When setting the goal that the bid wants to achieve, it follows that it is the efficiency and the maximum realised income of the seller. Depending on the type of goods we trade, for example fruit and vegetables, cereals, these two strategic goals before the auction can be harmonised but sometimes even conflicting. When these two goals are conflicting, it is possible that a particular auction allows the seller to earn a high income, but that the allocation is inefficient in the sense that the goods are not awarded to the bidder(s) who value it most. Also in terms of auction trading by auction method, it is possible that the allocation is effective, but that the seller achieves a low level of sales. On the basis of everything exposed, it can be noted that market information is a very important factor in organising auctions. One of the worst assumptions of auctioning is the inability to know the number and strength of potential participants at the auction. Therefore, it can be concluded when it comes to trade in agro-industrial products, primarily fruit and vegetables, that wholesale markets are a very efficient place for achieving the goals of sellers, customers and auction organisers. The importance of 
auctions is clear when we have in mind that they are used for the sale of oil and gas. From the aforementioned known historical and practical facts, we can conclude that our goal in this paper was achieved in terms of emphasising their importance for trade. When considering the market for agroindustrial products, it is necessary to emphasise the trade in the famous fairgrounds in the world. Agricultural products have the significance of both nutrition and human health, and the controlled wholesale and retail trade system is important in the system of the entire agro-industrial complex. Like any other type of trade in the market, it has its advantages and disadvantages, but considering the overall importance of agro-industry, as well as the quantity, quality and price of products we can conclude that auctions on wholesale markets would improve the total trade volume.

\section{References}

Acin-Sigulinski, S. (2008). Međunarodno poslovanje. Pigmaltion, Novi Sad.

Benny, M., Manfred, T. (1998). Goethes Second-Price Auction, The Journal of Political Economy, 106 (4), 854-859.

Benjamin, E., Ostrovsky, M., Schwarz, M. (2007). Internet Advertising and the Generalized Second-Price Auction, American Economic Review, 97 (1), 242259.

Đorđević, D., Klincov, D. (2008). Mikroekonomija. Univerzitet za poslovne studije, Banja Luka.

Jovanović, R. (2013). Ekonomika Poljoprivrede u ruralnim sredinama Srbije, Ekonomski signali, 8 (1), 117-128.

Kuzman, B., Prdić, N., Dobraš, Z. (2017). The importance of the wholesale markets for trade in agricultural products, Ekonomika poljoprivrede, 64 (3), 1177-1190.

Kuzman, B., Prdić, N. (2018). Sustainable agriculture and rural development in terms of the Republic of Serbia strategic goals realization within the danube region. Strategic significance of wholesale markets in agricurtural products sale, Institute of agricultural economics Belgrade, 87-104.

Mihailović, B., Cvijanović, D., Milojević, I., Filipović, M. (2014). The role of irrigation in development of agriculture in srem disctrict, Ekonomika poljoprivrede, 61 (4), 989-1004.

Mihailović, B., Simonović, Z., Ćurčić, N. (2017). Agricultural resources and development priorities of the municipality of Stara Pazova, Ekonomika poljoprivrede, 64 (1), 259-274.

Mihajlović. M. (2016). Odnos menadžmenta preduzeća i korporativnog upravljanja, Oditor, 2 (1), 2-10.

Prdić, N. (2017). Competition of Fairs on the Basis of the Composition Distribution, Industrija, 45 (3), 23-37.

Simonović, Z. (2014). Upravljanje agrarom Srbije u tranziciji. Institut za ekonomiku poljoprivrede, Beograd, 177. 
Subić, J. (2017). Assessment of investments by the use of sofware application for development of the business plan in agriculture, Ekonomika, 63 (2), 1-14.

Vlahović, B. (2013). Tržište agroindustrijskih proizvoda. Univerzitet u Novom SaduPoljoprivredni fakultet, Novi Sad.

Zakon o trgovini (2013). Službeni glasnik Rebublike Srbije, 53 (2010), 10 (2013). 